\section{Evaluating the Storage of Elephant Ears Acclimatized from Tissue Culture}

\author{
James E. Faust ${ }^{1}$, \\ Jeffrey W. Adelberg ${ }^{1}$, \\ Kelly P. Lewis ${ }^{1}$, and \\ Genhua Niu ${ }^{2}$
}

ADDITIONAL INDEX WORDs. imperial taro, temperature

SumMARY. The effects of storage temperature and shoot preparation of elephant ears (Colocasia antiquorum 'Illustris') were examined to determine how to successfully store plants prior to greenhouse forcing. A series of experiments were conducted that provided storage temperatures of 4 , $7,10,13$, or $16^{\circ} \mathrm{C}(39.2,44.6,50.0$, 55.4 , or $60.8^{\circ} \mathrm{F}$ ), and plants were placed into storage with the shoots uncut or cut to $3.0 \mathrm{~cm}$ (1.18 inches) above the surface of the growing medium. The storage duration ranged from 40 to 49 days. All plants stored at 4 or $7{ }^{\circ} \mathrm{C}$ died. Plant survival was $89 \%$ to $100 \%$ at $10{ }^{\circ} \mathrm{C}$, while plant survival was $100 \%$ at 13 or $16^{\circ} \mathrm{C}$. Shoot emergence and plant growth was faster following storage at 13 and $16^{\circ} \mathrm{C}$, than storage at $10^{\circ} \mathrm{C}$. Storage at $16^{\circ} \mathrm{C}$ resulted in leaf growth occurring during storage, which was undesirable. Removing shoots prior to storage had no effect on plant survival and performance during forcing. A fungicide drench with iprodione immediately prior to storage did not improve plant survival. This study suggests that $13{ }^{\circ} \mathrm{C}$ is near the base temperature for leaf development of elephant ears, thus the plants survive at this temperature with no growth occurring. Shoot removal prior to storage is recommended in order to optimize storage room space.

\footnotetext{
Technical Contribution No. 5032 of the Clemson University Experiment Station. This material is based upon work supported by CSREES/USDA, under project number SC- 1700135

${ }^{1}$ Department of Horticulture, D-136 P\&A Building, Clemson University, Clemson, SC 29634

${ }^{2}$ Alternate Crops and Systems Lab, BARC-W, ARS USDA, Beltsville, MD 20705.
}

$\mathrm{E}$ lephant ears or taro (Colocasia affinis, $C$. antiquorum, $C$. esculenta, $C$. gigantea, and Alocasia macrorrbizos) are herbaceous perennials, valued in the landscape for their large leaf blades and long petioles. Originally grown in Zones 8-10 (USDA Hardiness Zone Map), modern cultivars have been selected for reliable cold-hardiness in Zone 7 (Avent, 2001). Anthocyanin pigmentation in varied regions of the foliage creates an array of attractive "black" patterned types. Clonal propagation is required to maintain the cold-hardy, colored cultivars. Micropropagation of these modern selections is commonly used to fill current commercial demand.

Elephant ears are most often produced in outdoor nurseries in the southern U.S. Liners are transplanted into containers during the summer, overwintered in cold frames, then marketed the following spring. Newer elephant ear cultivars do not form large tubers and are best over-wintered in containers. It is considered essential to establish elephant ears outdoors in Zone 7 before August, so the plants will be sufficiently mature to be cold hardy for the winter (T. Avent, personal communication).

It has been clearly demonstrated that temperature is the most important factor controlling the growth and development of geophytes, which can actively grow at temperatures ranging from -2 to $34{ }^{\circ} \mathrm{C}\left(28.4\right.$ to $\left.93.2^{\circ} \mathrm{F}\right)$ (Hartsema, 1961). The hardiness of flower bulbs, including corms, tubers and rhizomes, has been classified into seven groups based on the temperature below which injury occurs (De Hertogh and Le Nard, 1993). This temperature is particularly important for geophyte storage, since there is limited protection from temperature extremes (De Hertogh and Le Nard, 2002).

The focus of this research was to determine how to grow elephant ears in a relatively fast production system that begins with micropropagated plantlets that are transplanted and grown in a greenhouse, then placed into a dark, temperature-controlled storage room to hold the plants until they are returned to the greenhouse for forcing. This approach has the potential to allow the grower to transplant liners over several weeks, store them in a cooler, then bring the plants out of the cooler to force the crop for a specific market date or to maintain the plants in a non-growing or dormant state until they can be shipped via mail order. The objective of this research was to establish the proper storage temperature conditions and shoot preparation technique for imperial taro, elephant ears.

\section{Materials and methods}

General procedures. Acclimatized tissue-cultured plantlets from liquid culture (Adelberg and Toler, 2004) were received from a commercial tissue culture lab. Individual plantlets were separated and placed on a mist propagation bench for 3 weeks. The mist was applied for $4 \mathrm{~s}$ every $20 \mathrm{~min}$. The greenhouse propagation environment averaged $22.7^{\circ} \mathrm{C}\left(72.86^{\circ} \mathrm{F}\right)$ and $51.2 \%$ relative humidity $(\mathrm{RH})$. The rooted plants were transplanted into 15.2 -cm-diameter (6.0 inches) pots containing a peat-based growing media (Fafard 3B; Fafard Inc., Anderson, S.C.) and placed into a greenhouse. The plants were grown until thickened roots with new shoot-tips were observed. Then, four storage experiments were initiated. During storage, plants were irrigated as necessary, since a preliminary experiment showed that drought stress during storage resulted in plant death. Following each storage experiment, the plants were returned to the greenhouse for forcing. Ambient photoperiods (lat. $34^{\circ} \mathrm{N}$, Clemson, S.C.) were maintained for all experiments while the plants were in the greenhouse.

Expt. 1. Forty-two plants were removed from propagation on $17 \mathrm{Dec}$. transplanted, and grown in a greenhouse that averaged $24.3{ }^{\circ} \mathrm{C}(75.74$ ${ }^{\circ} \mathrm{F}$ ) and $43.5 \%$ RH. On 21 Feb., half of the plants were cut $3.0 \mathrm{~cm}$ above the surface of the growing medium, while the other half of the plants remained intact (i.e., uncut). Cut and uncut plants were placed into dark storage rooms maintained at 4,10 or $16^{\circ} \mathrm{C}$, resulting in six treatments and seven plants per treatment. The plants were returned to the greenhouse after $49 \mathrm{~d}$ in storage. All aboveground plant material remaining on the uncut treatments was cut off $3.0 \mathrm{~cm}$ above the surface of the growing medium following the storage treatments. Data were collected after $49 \mathrm{~d}$ in the greenhouse during which time the greenhouse averaged $22.1^{\circ} \mathrm{C}$ $\left(71.78{ }^{\circ} \mathrm{F}\right)$ and $69.9 \% \mathrm{RH}$.

ExpT. 2. Sixty-four plants were 
removed from propagation on 7 Jan., transplanted, and grown in a greenhouse that averaged $21.8^{\circ} \mathrm{C}(71.24$ ${ }^{\circ} \mathrm{F}$ ) and 53.5\% RH. On 11 Apr., half of the plants were cut in the same manner as Expt. 1, while the other half of the plants remained uncut. The cut and uncut plants were placed into dark storage rooms maintained at $4,7,10$, or $13{ }^{\circ} \mathrm{C}$, resulting in eight treatments and eight plants per treatment. After 49 $\mathrm{d}$ in storage, the plants were returned to the greenhouse. All aboveground plant material remaining on the uncut treatments was cut off $3.0 \mathrm{~cm}$ above the surface of the growing medium following the storage treatments. Data were collected after $40 \mathrm{~d}$ in the greenhouse during which time the greenhouse averaged $24.5{ }^{\circ} \mathrm{C}(76.10$ ${ }^{\circ} \mathrm{F}$ ) and $74.0 \% \mathrm{RH}$.

Expt 3. On 4 Feb., 168 plants were removed from propagation, transplanted, and grown in a greenhouse that averaged $21.1{ }^{\circ} \mathrm{C}\left(69.98^{\circ} \mathrm{F}\right)$ and $63.9 \%$ RH. On 30 May, all of the plants were cut $3.0 \mathrm{~cm}$ above the surface of the growing medium and placed into dark storage rooms maintained at 7,10 , or $13^{\circ} \mathrm{C}$, resulting in three treatments and 56 plants per treatment. After $40 \mathrm{~d}$ in storage, the plants were returned to the greenhouse. Data were collected after $26 \mathrm{~d}$ in the greenhouse during which time the greenhouse averaged $25.4^{\circ} \mathrm{C}$ $\left(77.72^{\circ} \mathrm{F}\right)$ and $75.8 \% \mathrm{RH}$.

Expt 4. Twenty-eight plants were removed from propagation on 24 Jan., transplanted, and grown in a greenhouse that averaged $21.3^{\circ} \mathrm{C}(70.34$ ${ }^{\circ} \mathrm{F}$ ) and $62.0 \% \mathrm{RH}$. On $30 \mathrm{May}$, all of the plants were cut $3.0 \mathrm{~cm}$ above the surface of the growing medium. Half of the plants were treated with a drench of $0.124 \mathrm{~g}(0.00437 \mathrm{oz})$ per pot a.i. iprodione. Iprodione is a systemic fungicide used for the control of Botrytis cinerea. The other half of the plants received a water drench prior to being placed into a dark storage rooms at 10 or $13{ }^{\circ} \mathrm{C}$, resulting in four treatments and seven plants per treatment. After 40 $\mathrm{d}$ in storage, the plants were returned to the greenhouse. Data were collected after $26 \mathrm{~d}$ in the greenhouse during which time the greenhouse averaged $25.4^{\circ} \mathrm{C}$ and $75.8 \% \mathrm{RH}$.

Data Collection and analysis. The data collected were plant survival, days to shoot emergence, shoot number, and shoot fresh weight. Shoot emergence was defined as the first leaf unfolding away from the plant sheath (the base of the petioles emerging from the growing medium). Shoot number referred to the number of aboveground shoots that emerged following storage. Shoot fresh weight included all plant tissue above the surface of the growing medium. ANOVA were performed with PROC GLM (SAS Institute, Cary, N.C.). Expts. 1, 2, and 4 were split plot designs with the shoot preparation or fungicide treatment occurring split within temperature. Expt. 3 was a completely randomized design. Treatment means were compared using Tukey's Studentized range test ( $5 \%$ level). Treatments that had 0\% plant survival could not be statistically analyzed.

\section{Results and discussion}

STORAge TEMPERATURe. In Expts. $1-3$, all plants stored at 4 or $7^{\circ} \mathrm{C}$ for 40 to $49 \mathrm{~d}$ died (Tables $1-2$ ). When containers were removed from the storage rooms, no viable plant tissue was observed above or in the growing medium. Visual observations indicated that the plants lost integrity (i.e., became mushy) during the first 1 to 2 weeks in storage at $4{ }^{\circ} \mathrm{C}$, while at 7 ${ }^{\circ} \mathrm{C}$, the plants lost integrity during the first 3 to 4 weeks.

Table 1. The effect of storage temperature and shoot preparation on the performance of elephant ears (Colocasia antiquorum 'Illustris') following $49 \mathrm{~d}$ in storage. The shoot preparation treatment consisted of cutting half the plants $\mathbf{3 . 0}$ $\mathrm{cm}$ (1.18 inch) above the surface of the growing medium, while the other half remained intact (i.e., uncut). For Expts. 1 and 2, data were collected 49 and 40 $\mathrm{d}$, respectively, after the plants were removed from storage and placed in a greenhouse. Means represent seven and eight plants for Expts. 1 and 2, respectively.

\begin{tabular}{|c|c|c|c|c|c|}
\hline Temp & $\begin{array}{c}\text { Shoot } \\
\text { preparation }\end{array}$ & $\begin{array}{c}\text { Survival } \\
(\%)\end{array}$ & $\begin{array}{l}\text { Time to } \\
\text { emergence } \\
\text { (d) }\end{array}$ & $\begin{array}{c}\text { Shoot } \\
\text { fresh wt } \\
(\mathrm{g})^{\mathrm{z}}\end{array}$ & $\begin{array}{c}\text { Shoots } \\
\text { (no.) }\end{array}$ \\
\hline \multicolumn{6}{|c|}{ Expt. 1} \\
\hline \multirow[t]{2}{*}{$4^{\circ} \mathrm{C}\left(39.2^{\circ} \mathrm{F}\right)$} & Cut & 0 & $---y$ & --- & --- \\
\hline & Uncut & 0 & --- & --- & --- \\
\hline \multirow[t]{2}{*}{$10^{\circ} \mathrm{C}\left(50.0^{\circ} \mathrm{F}\right)$} & Cut & 89 & $17.0 \mathrm{a}^{\mathrm{x}}$ & $46.3 \mathrm{ab}$ & $3.3 \mathrm{a}$ \\
\hline & Uncut & 89 & $17.0 \mathrm{a}$ & $32.0 \mathrm{~b}$ & $2.6 \mathrm{a}$ \\
\hline \multirow[t]{3}{*}{$16^{\circ} \mathrm{C}\left(60.8^{\circ} \mathrm{F}\right)$} & Cut & 100 & $1.4 \mathrm{~b}$ & $77.2 \mathrm{a}$ & $2.5 \mathrm{a}$ \\
\hline & Uncut & 100 & $8.6 \mathrm{ab}$ & $58.3 \mathrm{ab}$ & $1.9 \mathrm{a}$ \\
\hline & & Expt. 2 & & & \\
\hline \multirow[t]{2}{*}{$4^{\circ} \mathrm{C}\left(39.2^{\circ} \mathrm{F}\right)$} & Cut & 0 & --- & --- & --- \\
\hline & Uncut & 0 & --- & --- & --- \\
\hline \multirow[t]{2}{*}{$7^{\circ} \mathrm{C}\left(44.6^{\circ} \mathrm{F}\right)$} & Cut & 0 & --- & --- & --- \\
\hline & Uncut & 0 & --- & --- & --- \\
\hline \multirow[t]{2}{*}{$10^{\circ} \mathrm{C}\left(50.0^{\circ} \mathrm{F}\right)$} & Cut & 100 & $9.9 \mathrm{a}$ & $57.1 \mathrm{c}$ & $6.5 \mathrm{a}$ \\
\hline & Uncut & 100 & $9.0 \mathrm{a}$ & $96.9 \mathrm{~b}$ & $7.9 \mathrm{a}$ \\
\hline \multirow[t]{2}{*}{$13^{\circ} \mathrm{C}\left(55.4^{\circ} \mathrm{F}\right)$} & Cut & 100 & $3.4 \mathrm{~b}$ & $132.0 \mathrm{a}$ & $5.5 \mathrm{a}$ \\
\hline & Uncut & 100 & $4.4 \mathrm{~b}$ & $119.5 \mathrm{ab}$ & $4.3 \mathrm{a}$ \\
\hline
\end{tabular}

$28.35 \mathrm{~g}=1.0 \mathrm{oz}$.

y Plants did not survive the storage treatment, so data were not collected.

'Letters indicate significant differences within column and experiment based on Tukey's Studentized range test (5\% level). 
Table 2. The effect of storage temperature on the performance of elephant ears (Colocasia antiquorum 'Illustris') following $40 \mathrm{~d}$ in storage (Expt. 3). The shoot preparation treatment consisted of cutting half the plants $\mathbf{3 . 0}$ $\mathrm{cm}$ ( 1.18 inch) above the surface of the growing medium, while the other half remained intact (i.e., uncut). Data were collected $26 \mathrm{~d}$ after the plants were removed from storage and placed in a greenhouse. Means represent 56 plants.

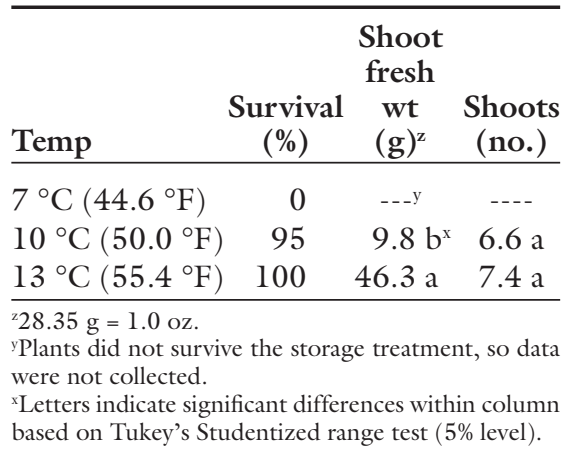

ment was used in Expts. 2-4 rather than $16{ }^{\circ} \mathrm{C}$. The base of the petioles remained in tack during storage at 13 ${ }^{\circ} \mathrm{C}$, yet the smallest leaves within the sheath did not emerge.

The shoot fresh weight data following storage were collected at an earlier date in Expts. 3 and 4 than in Expts. 1 and 2. As a result, a clearer differentiation of the effect of storage temperature on shoot growth following storage was observed in Expts. 3 and 4 (Tables 2-3). Shoot growth following storage at $13{ }^{\circ} \mathrm{C}$ was considerably faster than following storage at $10{ }^{\circ} \mathrm{C}$. The base of the petioles slowly decayed during storage at $10^{\circ} \mathrm{C}$. After
2 weeks in storage, Botrytis spores completely covered the aboveground plant tissues. Over time the petioles decayed down to the belowground stem tissue. In most cases, the decay stopped at the stem, and the meristem was preserved. Therefore, shoot growth following storage at $10^{\circ} \mathrm{C}$ was relatively slow because all leaves had to emerge from the stem tissue. In contrast, shoot growth following storage at $13{ }^{\circ} \mathrm{C}$ was faster because immature leaves remained intact inside the sheath of the petioles. These leaves emerged within a few days after the plants were placed in the greenhouse.

Storage temperature had no effect on the number of shoots emerging from the growing media following storage.

Fungicide. Expt. 4 was conducted to determine if a higher survival rate would be observed in the $10^{\circ} \mathrm{C}$ treatment if a fungicide was applied prior to storage to reduce pathogen infection and deterioration of the plant tissues. Iprodione is a systemic fungicide, so there is greater potential for protecting plant tissues during storage. Visual observations indicated that the onset of Botrytisinfection was delayed, but no benefit in terms of survival or regrowth following storage were observed (Table 3).

Shoot PREPARATION. Shoot removal is highly desirable in a commercial situation due to the reduced shelf height required during storage which allows for higher plant density in the storage room. In Expts. 1 and 2 , cutting shoots prior to storage had no significant effect on plant survival, days to emergence, or number of shoots emerging following storage (Table 1). No consistent effect on shoot fresh weight following storage was observed.

Leaf, stem and root dry weights were recorded on six plants prior to placing the plants into the storage treatments for Expt. 2 (Table 4). These data indicated that the leaves and petioles contained $58 \%$ of the dry weight of the entire plant. The petiole tissue left intact on the plants accounted for $14 \%$ of the total plant dry weight, while the leaf and petiole tissue removed accounted for $44 \%$ of plant dry weight. The stem and roots contained $17 \%$ and $25 \%$ of the plant dry weight, respectively. Despite the relatively large percentage of dry weight removed during shoot removal, no deleterious effects of shoot removal were observed. Theoretically, leaving the shoots on plants during storage allows the plant to prepare for dormancy by mobilizing carbohydrates from the leaves to the stems and rhizomes. However, Colocasia antiquorum is native to semiaquatic environments in Indonesia, so it is possible that it is never experiences a period of dormancy during its natural lifecycle and thus lacks this mechanism.

In summary, temperature is a critical factor affecting the storage of elephant ears. A $13^{\circ} \mathrm{C}$ storage temperature proved to be very effective. We expect that a storage duration greater than 7 weeks could be achieved at 13 ${ }^{\circ} \mathrm{C}$; however, the prestorage greenhouse environment, such as temperature and light levels, may impact storage
Table 3. The effect of storage temperature and drench treatment on the performance of elephant ears (Colocasia antiquorum 'Illustris') following $40 \mathrm{~d}$ in storage (Expt. 4). For the drench treatment, a drench of $0.124 \mathrm{~g}(0.00437$ oz) per pot a.i. iprodione or water was applied immediately before the plants were placed into the storage environment. Data were collected $26 \mathrm{~d}$ after the plants were removed from storage and placed in a greenhouse. Means represent seven plants.

\begin{tabular}{llccc}
\hline Temp & Drench & $\begin{array}{c}\text { Survival } \\
(\%)\end{array}$ & $\begin{array}{c}\text { Shoot } \\
\text { fresh wt } \\
(\mathbf{g})^{\mathrm{z}}\end{array}$ & $\begin{array}{c}\text { Shoots } \\
(\text { no. })\end{array}$ \\
\hline $10{ }^{\circ} \mathrm{C}\left(50.0^{\circ} \mathrm{F}\right)$ & Water & 100 & $7.4 \mathrm{~b}^{\mathrm{y}}$ & $5.9 \mathrm{~b}$ \\
& Iprodione & 100 & $4.8 \mathrm{~b}$ & $6.0 \mathrm{~b}$ \\
$13{ }^{\circ} \mathrm{C}\left(55.4^{\circ} \mathrm{F}\right)$ & Water & 100 & $49.3 \mathrm{a}$ & $11.0 \mathrm{a}$ \\
& Iprodione & 100 & $52.4 \mathrm{a}$ & $8.0 \mathrm{ab}$ \\
\hline
\end{tabular}

${ }^{2} 28.35 \mathrm{~g}=1.0 \mathrm{oz}$

'Letters indicate significant differences within column based on Tukey's Studentized range test $(5 \%$ level $)$.
Table 4. Mean fresh and dry weight of six elephant ears (Colocasia antiquorum 'Illustris') measured immediately prior to placing the plants into the storage treatments for Expt 2. Leaf and petiole represents the tissue removed from the cut shoot preparation treatment, in which the plants were cut $3.0 \mathrm{~cm}$ (1.18 inch) above the surface of the growing medium prior to storage. Petiole represents the tissue left below the cut and above the stem tissue. Stem represents the primary stem, while the rhizomatous shoots were included as part of the root tissue. The percentage of the whole plant weight represented by the individual plant part is shown in parentheses.

\begin{tabular}{lcc}
\hline Plant part & Fresh wt & Dry wt \\
\hline & $----[\mathrm{g}(\%$ whole plant $)]----$ \\
Leaf and petiole (above cut) & $88.3(42 \%)$ & $7.9(44 \%)$ \\
Petiole (below cut) & $32.2(15 \%)$ & $2.5(14 \%)$ \\
Stem & $18.4(9 \%)$ & $2.9(16 \%)$ \\
Roots & $70.8(34 \%)$ & $4.6(26 \%)$ \\
Whole plant & $209.7(100 \%)$ & $17.9(100 \%)$ \\
\hline
\end{tabular}


duration. The decline in plant survival that occurred at $10{ }^{\circ} \mathrm{C}$ was a gradual process, so we expect that storage at $10{ }^{\circ} \mathrm{C}$ for a shorter duration than used in this study might yield satisfactory results. Storage temperatures at 16 ${ }^{\circ} \mathrm{C}$ resulted in undesirable leaf growth during storage, so $16^{\circ} \mathrm{C}$ storage is not recommended, despite the 100\% survival rate. No significant differences were observed between cut and uncut plants, so shoot removal prior to storage is the desired commercial treatment. Fungicide treatments in this study did not improve plant performance following storage.

\section{Literature cited}

Adelberg, J. and J. Toler. 2004. Comparison of agar and an agitated, thin-film liquid system for micropropagation of ornamental elephant ears. HortScience 39:1088-1092.

Avent, T. 2001. Aroid hardiness list. Intl. Aroid Soc. 8 Sept. 2004. <http://www. aroid.org/horticulture/hardy.html>.

De Hertogh, A.A and M. Le Nard. 1993. Physiological and biochemical aspects of flower bulbs, p. 21-28. In: A. De Hertog and M. Le Nard (eds.). The physiology of flower bulbs. Elsevier, Amsterdam, The Netherlands.

De Hertogh, A.A and M. Le Nard. 2002. Flower bulbs. In: K.C. Gross, C.Y. Wang, and M. Saltveit (eds.). The commercial storage of fruits, vegetables, and florist and nursery Crops. U.S. Dept. Agr., Agr. Hdbk. 66. 8 Sept. 2004. <http://www. ba.ars.usda.gov/hb66/index.html>.

Hartsema, A.M. 1961. Influence of temperatures on flower formation and flowering of bulbous and tuberous plants, $\mathrm{p}$. 123-167.In:W. Ruhland (ed.). Handbuch der Planzenphysiologie. Springer Verlag, Berlin. 